\title{
New records of lichens from the Russian Far East. III. Lichens of coastal habitats
}

\author{
E. A. Davydov ${ }^{1,6}$, L. S. Yakovchenko ${ }^{2,7 *}$, I. A. Galanina ${ }^{2,8}$, A. G. Paukov ${ }^{3,9}$, I. V. Frolov ${ }^{4,10}$, T. Ahtit \\ ${ }^{1}$ Altai State University, Lenina Pr. 61, Barnaul, 656049, Russian Federation \\ ${ }^{2}$ Federal Scientific Center of the East Asia Terrestrial Biodiversity FEB RAS, Stoletiya Vladivostoka Pr. 159, \\ Vladivostok, 690022, Russian Federation \\ ${ }^{3}$ Institute of Natural Sciences and Mathematics, Department of Biology, Ural Federal University, Lenina Pr. 51, \\ Ekaterinburg, 620000, Russian Federation \\ ${ }^{4}$ Russian Academy of Sciences, Ural Branch: Institute Botanic Garden, 8 Marta St. 202a, Ekaterinburg, \\ 620144, Russian Federation \\ ${ }_{5}^{5}$ Botany Department, Finnish Museum of Natural History, University of Helsinki, P.O. Box 7, 00014, Finland \\ ${ }^{6}$ E-mail: eadavydov@yandex.ru; ORCID iD: https://orcid.org/0000-0002-2316-8506 \\ ${ }^{7}$ E-mail: lidiyakovchenko@mail.ru; ORCID iD: https://orcid.org/0000-0002-4342-7771 \\ ${ }^{8}$ E-mail: gairka@yandex.ru; ORCID iD: https://orcid.org/0000-0001-9029-2470 \\ ${ }^{9}$ E-mail: alexander_paukov@mail.ru; ORCID iD: https://orcid.org/0000-0001-6689-7189 \\ ${ }^{10}$ E-mail: ivfrolov@gmail.com; ORCID iD: https://orcid.org/0000-0003-4454-3229 \\ ${ }^{11}$ E-mail: teuvo.ahti@helsinki.fi; ORCID iD: https://orcid.org/0000-0001-7549-0962
}

Keywords: biogeography, East Asia, Kuril Islands, Primorye Territory, Sakhalin Island.

Summary. Aspicilia subepiglypta, Buellia subdisciformis, Calogaya arnoldii, Flavoplaca flavocitrina, Lecanora swartzii, and Lecidella scabra are reported as new records for the Russian Far East. Rinodina gennarii and Lecidella asema are newly recorded for the mainland of the Russian Far East. Rare lichens Cladonia subconistea and Leptotrema litophila are newly found in coastal habitats; Caloplaca atroflava is new for Sakhalin Island, and Umbilicaria vellea is new for Kuril Islands.

\section{Новые находки лишайников для российского Дальнего Востока III. Лишайники приморских местообитаний}

\footnotetext{
Е. А. Давыдов ${ }^{1}$, Л. С. Яковченко ${ }^{2}$ И. А. Галанина ${ }^{2}$, А. Г. Пауков ${ }^{3}$, И. В. Фролов ${ }^{4}$, Т. Ахти ${ }^{5}$

${ }^{1}$ Алтайский государственный университет, пр. Ленина, 61, г. Барнаул, 656049, Россия

${ }^{2}$ Федеральный научный иеентр биоразнообразия наземной биоты Восточной Азии ДВО РАН, пр. Столетия Владивостока, 159, г. Владивосток, 690022, Россия
${ }^{3}$ Институт естественных наук и математики, Уральский федеральный университет, пр. Ленина, 51, г. Екатеринбург, 620000, Россия

${ }^{4}$ Ботанический сад-институт УРО РАН, ул. 8 марта, 202а, г. Екатеринбург, 620144, Россия

${ }^{5}$ Отдел Ботаники, Финский музей истории природы, Университет Хельсинки, а/я 7, 00014, г. Хельсинки, Финляндия
} 
Ключевые слова: биогеография, Восточная Азия, Курильские острова, Приморский край, Сахалин.

Аннотация. Aspicilia subepiglypta, Buellia subdisciformis, Calogaya arnoldii, Flavoplaca flavocitrina, Lecanora swartzii и Lecidella scabra приводятся впервые для российского Дальнего Востока. Rinodina gennarii и Lecidella asema впервые приводятся для материковой части российского Дальнего Востока. Редкие лишайники Cladonia subconistea и Leptotrema litophila впервые найдены в приморских местообитаниях; Caloplaca atroflava - новый вид для Сахалина, Umbilicaria vellea - новый вид для Курильских островов.

\section{Introduction}

Russian Far East is a vast territory, adjacent to the Pacific Ocean, which stretches from the Chukotka Peninsula in the North to the Primorye Territory in the South. The area of the region is more than 3 million square kilometers, which is approximately $18 \%$ of the total territory of Russia. It is geographically divided into three parts: arctic, northern and southern regions. The latter includes five administrative provinces: Amur Region, Jewish Autonomous Region, Primorye Territory, Sakhalin Region and the southern part of Khabarovsk Territory. The region has a mainly mountainous ground profile. Inland mountains and highlands have smooth slopes without pronounced ridges or canyons. In the territories situated closer to the Pacific Ocean high and pointed rocks and steep cliffs are common. In some regions of the Russian Far East the border of the subalpine zone descends closely to the seashore (Urusov, 2018).

The descriptions of the region, its climate, and the history of lichen studies as well as some new and interesting records of lichens for the Far East of Russia are published in our previous papers (Yakovchenko et al., 2019, 2020; Davydov et al., 2021). Here we report on the findings of several species new to the Russian Far East and further detailed information on rarely reported species along with their identification characters, images, and distribution.

\section{Materials and methods}

Morphological observations were made using a dissecting microscope. Cross-sections of apothecia and thalli were made by hand with a razor blade and observed after mounting in water using a microscope. Measurements of spores and conidia are presented as follows: (smallest value recorded) $(\mathrm{X}-\mathrm{SE})-\mathrm{X}-(\mathrm{X}+\mathrm{SE})$ (largest value recorded), where $\mathrm{X}$ is the (arithmetic) sample mean, and SE is the sample error of mean. The measurements were made with the precision of $0.5 \mu \mathrm{m}$. Polarized light (pol) was used for locating crystals in the sections.
Lichen substances of some species were studied by spot-tests using potassium hydroxide solution (K), sodium hypochlorite solution (C), 1,4-p-phenylendiamine (Pd), and iodine (I), and by a thin-layer chromatography (TLC) in solvent systems A, B and (Orange et al., 2001).

\section{Results and discussion}

\section{New records for the Russian Far East}

Aspicilia subepiglypta S. Y. Kondr., L. Lőkös et J.-S. Hur (Fig. 1)

Specimen examined: "Russia, Primorye Territory, N coast of Russkiy Is., to E of Vyatlin Cape, rocks, $42^{\circ} 57^{\prime} 30.4^{\prime \prime} \mathrm{N}, 131^{\circ} 54^{\prime} 2.8^{\prime \prime} \mathrm{E}$, elev. 30 m, on sandstone. 14 VIII 2014. A. G. Paukov 3294" (UFU-L3495).

Chemistry: norstictic acid, traces of connorstictic and hyposalazinic acids (TLC AP 82-07).

The species was recently described from Korea, where it grows on siliceous rocks from a coastal zone to higher localities (Kondratyuk et al., 2016). Aspicilia subepiglypta (Fig. 1) belongs to the $A$. cinerea sensu lato, but morphological characters do not allow distinguishing these two species with absolute confidence. Similarly, Aspicilia subepiglypta represents only one, not clearly separated branch of several branches in ITS phylogenetic trees of Aspicilia cinerea s. 1., however we support the segregation of this species as follows. The morphological characters, which can help in distinction of the two taxa, are the thicker thallus $(0.2-0.5 \mathrm{~mm})$, together with the immersed, numerous on areoles, apothecia without a prominent thalline margin in Aspicilia subepiglypta. Additionally, the studied specimens have statistically shorter conidia (8.0-)12.6-12.9$13.2(-18.0) \mu \mathrm{m}(\mathrm{n}=97)$ versus $(12.0-) 16.6-16.9-$ $17.3(-22.0) \mu \mathrm{m}$ in Aspicilia cinerea $(\mathrm{n}=45)$, and larger spores $(18.0-) 20.5-20.7-21.0(-25.0) \mu \mathrm{m}$ $(\mathrm{n}=50)$ versus $(11.0-) 16.9-17.3-17.7(21.0) \mu \mathrm{m}$ $(\mathrm{n}=25)$ in Aspicilia cinerea. Aspicilia exserta Hue described from Korea has conidia of the similar size to those of A. subepiglypta, but in the size of 
spores and morphology of apothecia it is closer to A. cinerea, where it was previously moved (Paukov et al., 2017). We therefore prefer to retain Aspicilia exserta in A. cinerea.

Buellia subdisciformis (Leight.) Vain. (Fig. 2)

Specimen examined: "Russia, Primorye Territory, $\mathrm{N}$ coast of Russkiy Is. to E of Vyatlin Cape, rocks, $42^{\circ} 57^{\prime} 38^{\prime \prime} \mathrm{N}, 131^{\circ} 54^{\prime} 26^{\prime \prime} \mathrm{E}$, elev. $10 \mathrm{~m}$, on sandstone. 14 VIII 2014. E. A. Davydov 19370, L. S. Yakovchenko" (ALTB).

Buellia subdisciformis is a cosmopolitan coastal species in the xeric supralittoral (Coppins et al., 2009). In Russia it was only known from the Caucasus (Urbanavichus, 2010). It is characterized by the areolate, whitish thallus $(\mathrm{K}+\mathrm{red}$, norstictic acid, I-) with the black hypothallus and sessile, black apothecia with a greyish proper margin, brown epihymenium and a dark red-brown hypothecium. The similar species with a dark hypothecium and norstictic acid are Buellia aethalea (Ach.) Th. Fr., B. maritima (A. Massal.) Bagl., B. taishanensis Q. D. Wang et Z. F. Jia (Wang et al., 2018) recently described from China, and B. yoshimurae A. Higashi et al. (Higashi et al., 2017) described from Japan. Buellia aethalea differs by its immersed apothecia and aeruginose epihymenium; $B$. maritima is distinguished by the densely pruinose thallus with a chalky consistency and a paler (whitish to grey) hypothallus; Buellia taishanensis differs by its poorly-developed, darker (grey or grey-brown) thallus; B. yoshimurae - by its thallus, areolate in the center and rimose at the periphery, immersed apothecia and a medulla lacking calcium oxalate crystals.

Calogaya arnoldii (Wedd.) Arup, Frödén et Søchting (Fig. 3)

Specimen examined: "Russia, Sakhalin Region, Sakhalin Island, Makarov District, around cape Tikhiy, at $19 \mathrm{~km} \mathrm{~N}$ of Vzmor'e, $48^{\circ} 01^{\prime} 29.0^{\prime \prime} \mathrm{N}$, $142^{\circ} 32^{\prime} 58.2^{\prime \prime} \mathrm{E}$, elev. $5 \mathrm{~m}$, siliceous outcrops on the seashore, on rocks. 26 VI 2019. I. V. Frolov" (hb. I. V. Frolov).

This is a widespread saxicolous lichen in Europe and Asia. It was reported from different regions of Russia: Caucasus, South Siberia, Transbaikal Region, and the Urals (Vondrák et al., 2016). Calogaya arnoldii is a placodioid lichen with orange thallus and apothecia, without vegetative propagules. Morphologically it is very close to C. saxicola (Hoffm.) Vondrák. The differences between species are subtle and mostly concern shape and size of ascospores (Vondrák et al., 2016). Our finding is confirmed by the ITS sequence (not shown).

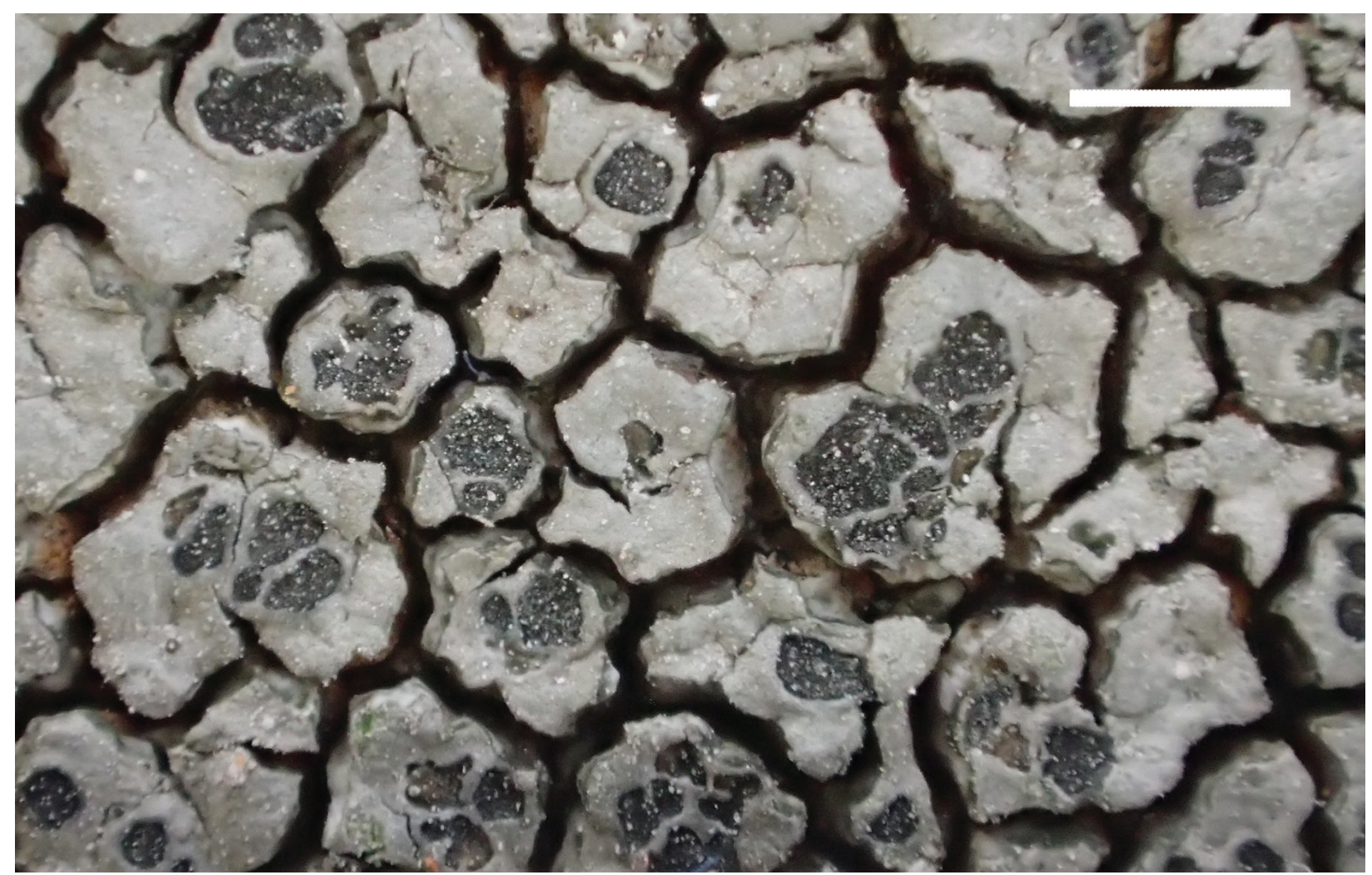

Fig. 1. Aspicilia subepiglypta (Paukov 3294, UFU). Scale $=1 \mathrm{~mm}$ (Photo: A. G. Paukov). 




Fig. 2. Buellia subdisciformis (Davydov 19370, Yakovchenko, ALTB). Scale $=1$ mm (Photo: E. A. Davydov).

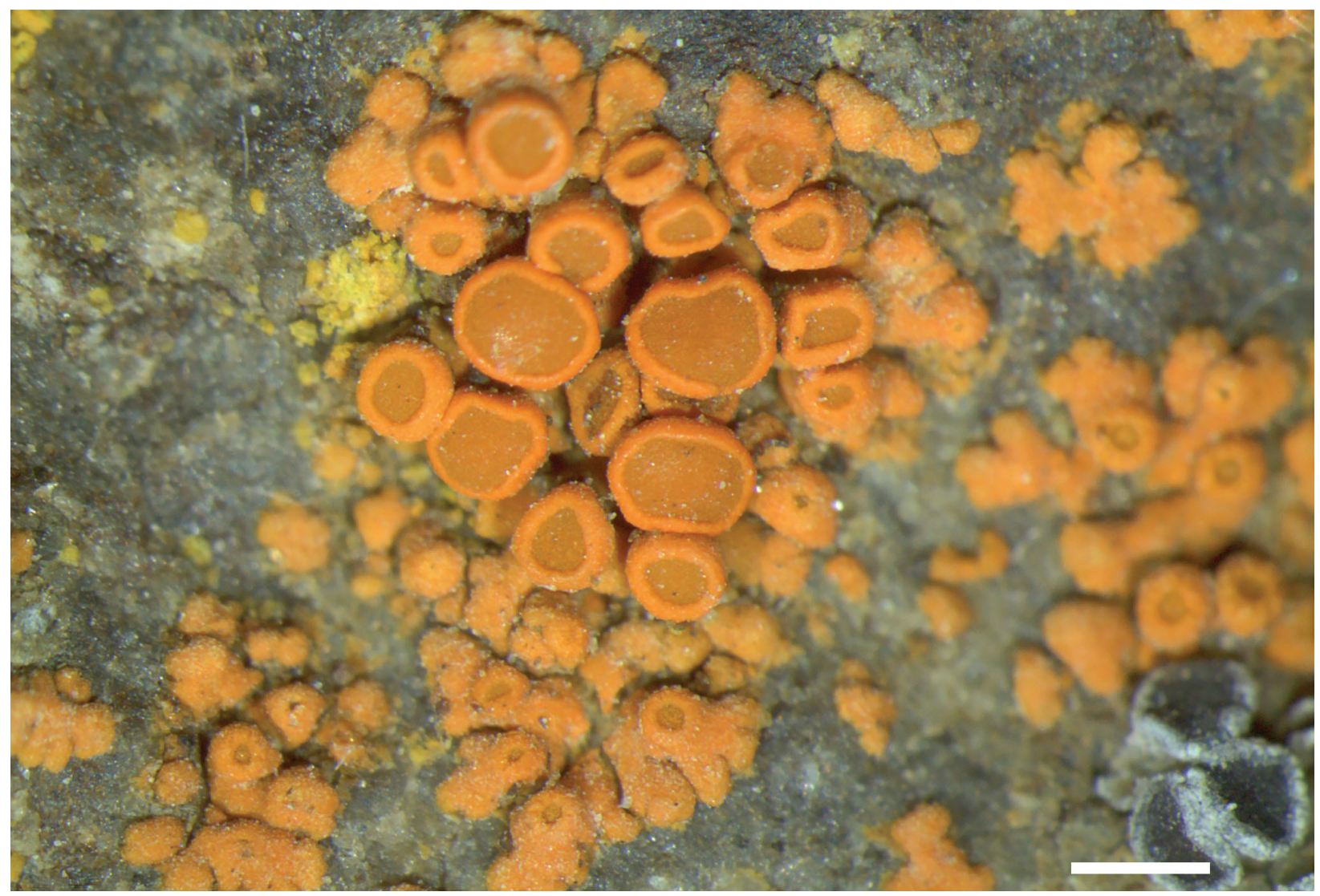

Fig. 3. Calogaya arnoldii from Sakhalin Island (Frolov s. n., hb. Frolov). Scale =0.5 mm (Photo: I. V. Frolov). 
Flavoplaca flavocitrina (Nyl.) Arup, Frödén et Søchting (Fig. 4)

Specimens examined: Russia, "Sakhalin Region, Sakhalin Island, Makarovskiy District, around cape Tikhiy, at $19 \mathrm{~km} \mathrm{~N}$ of Vzmor'e, $48^{\circ} 01^{\prime} 29.0^{\prime \prime} \mathrm{N}$, $142^{\circ} 32^{\prime} 58.2^{\prime \prime} \mathrm{E}$, elev. $5 \mathrm{~m}$, siliceous outcrops on the seashore, on rocks. 26 VI 2019, I. V. Frolov"; ibid., "about $1 \mathrm{~km} \mathrm{~W}$ of Zaozernoe, $48^{\circ} 21^{\prime} 35.9^{\prime \prime} \mathrm{N}$, $142^{\circ} 39^{\prime} 04.2^{\prime \prime} \mathrm{E}$, elev. $10 \mathrm{~m}$, old concrete dam in the Lazovaya River, on concrete. 27 VI 2019. I. V. Frolov" (hb. I. V. Frolov).

This is a common lichen in the Sakhalin Island, where it grows on a variety of rocks and on concrete in many maritime and inland localities. The species has a worldwide distribution and is known from Asia, Europe, Hawaii, North America, and Australia (Arup, 2006; Vondrák et al., 2016). In the Asian part of Russia the species was recorded in the Republic of Altai and in the Trans-Baikal Territory (Vondrák et al., 2016, 2019).

Flavoplaca flavocitrina is the species with a wide ecological range, which occurs on rocks and concrete, but it is also common on bark and wood. In its typical form, the species is characterized by the yellow apothecia and the yellow, areolate thallus with marginal soralia contrasting with the rest of the thallus.

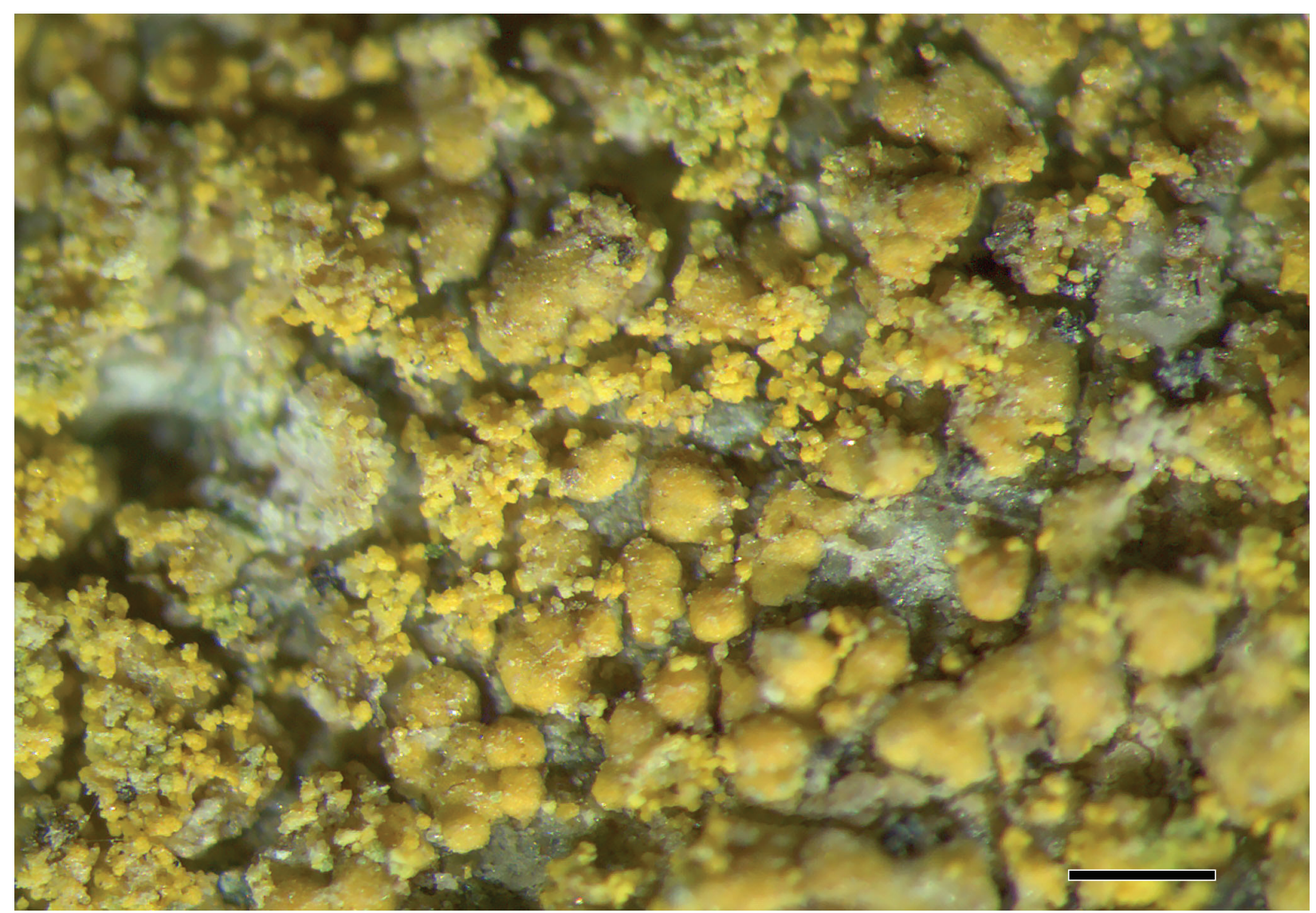

Fig. 4. Flavoplaca flavocitrina from Sakhalin Island (Frolov s. n., hb. Frolov). Scale = 0.2 mm (Photo: I. V. Frolov).

Lecanora swartzii (Ach.) Ach. (Fig. 5)

Specimens examined: "Russia, Primorye Territory, Dalnegorskiy District, Sikhote-Alin' Range, Japan Sea coast at $1.5 \mathrm{~km} \mathrm{SW}$ from the Lidovka Settlement, rocks, $44^{\circ} 24^{\prime} 22^{\prime \prime} \mathrm{N}$, $135^{\circ} 52^{\prime} 25^{\prime \prime}$, elev. $25 \mathrm{~m}$, on siliceous rocks. $17 \mathrm{VIII}$ 2014. E. A. Davydov 16533, L. S. Yakovchenko" (ALTB).

Lecanora swartzii is a cosmopolitan species growing on siliceous rocks in uplands (Edwards et al., 2009). In Russia it was reported from Caucasus,
South Siberia as well as the northern parts of the Urals and European Russia (Urbanavichus, 2010). In the Russian Far East it grows not directly on the seashore but on gravel barrens near the coast. The species has a warty-areolate to bullate or stalked areolate, yellowish-white thallus $(\mathrm{C}+$ yellow orange, $\mathrm{K}+$ yellow, $\mathrm{UV}+$ pale orange) and a white hypothallus. Apothecia lecanorine, plane to convex, markedly constricted at the base to stalked, with densely pruinose, yellowish-grey disc $(\mathrm{C}+$ yellow orange). From the similar species, Lecanora rupi- 
cola (L.) Zahlbr., it is easily distinguished by its $\mathrm{C}+$ yellow-orange thallus and the absence of phenocortex on the thalline margin. Lecanora swartzii shares the eucorticate amphithecium with genetically and ecologically similar species, Lecanora bicinctoi- dea Blaha et Grube, but differs from the latter by its C-negative thallus, a white hypothallus and soon constricted at the base to distinctly stalked apothecia (Blaha, Grube, 2007).

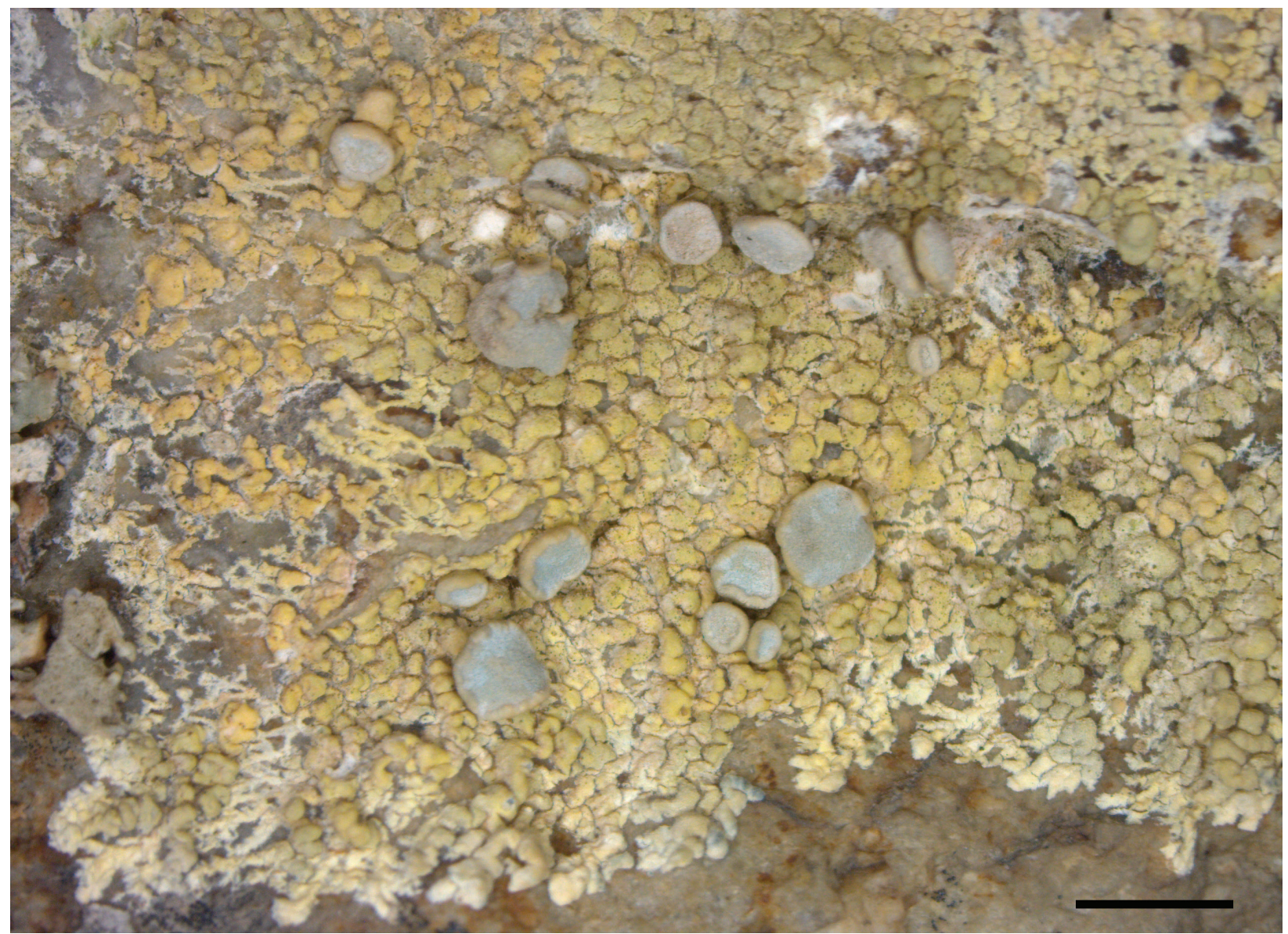

Fig. 5. Lecanora swartzii (Davydov 16533, Yakovchenko, ALTB). Scale = 1 mm (Photo: E. A. Davydov).

Lecidella scabra (Taylor) Hertel et Leuckert Specimens examined: "Russia, Primorye Territory, $\mathrm{N}$ coast of Russkiy Is., to $\mathrm{E}$ of Vyatlin Cape, rocks, $42^{\circ} 57^{\prime} 38^{\prime \prime} \mathrm{N}, 131^{\circ} 54^{\prime} 26^{\prime \prime} \mathrm{E}$, elev. $10 \mathrm{~m}$, on sandstone. 14 VIII 2014. E. A. Davydov 19312, L. S. Yakovchenko" (ALTB).

Chemistry: atranorin, thuringione and trace of arthothelin (TLC AP 291-11).

The species is distributed in Europe, Asia, Macaronesia, and North America (Fletcher et al., 2009; Esslinger, 2018) and occurs on siliceous or slightly basic rocks, often on walls and memorials, rarely on wood, worked timber or bark. In Russia it is known from South Siberia as well as the arctic and northern part of European Russia (Urbanavichus, 2010). It is characterized by a grayish with a yellowish tint, rimose-areolate to granular thallus; $\mathrm{K}+$ yellow, $\mathrm{C}+$ orange with discrete to confluent soralia, concolorous with the thallus composed of fine (ca. $20 \mu \mathrm{m}$ ) soredia. Apothecia black, lecideine, epihymenium green, hypothecium from dullyellow to brown. A similar species with vegetative propagules, Lecidella meiococca (Nyl.) Leuckert et Hertel, differs by its blastidiate thallus.

\section{New records for the mainland of Far East}

Lecidella asema (Nyl.) Knoph et Hertel (Fig. 6) Specimens examined: "Russia, Primorye Territory, $\mathrm{N}$ coast of Russkiy Is., to $\mathrm{E}$ of Vyatlin Cape, rocks, $42^{\circ} 57^{\prime} 38^{\prime \prime} \mathrm{N}, 131^{\circ} 54^{\prime} 26^{\prime \prime} \mathrm{E}$, elev. $10 \mathrm{~m}$, on sandstone. 14 VIII 2014, E. A. Davydov 18349, 19311, L. S. Yakovchenko" (ALTB).

This rare species was reported for the first time for Russia by Urbanavichus (2010) on the base of a specimen collected in the Irkutsk Region (South 
Siberia) and deposited in TSB, no. 29116 (Nimis, Martellos, 2017). Then, Skirina and Rodnikova (2014) recorded Lecidella asema from Bolshoi Pelis Island (Primorye Territory). Recently the species was found for the first time in the European Russia (Himelbrant et al., 2019). Here we are reporting the second locality of the species in Primorye Territory, which is the first record of the species from the continental part of the Far East. Worldwide, the species is known in Europe, Asia, Macaronesia, Africa, and North America (Fletcher et al., 2009; Moon, 2013; Esslinger, 2018; Ohmura, Kashiwadani, 2018), where it usually grows on supralittoral rocks and rocks in coastal mountains, while it is infrequent in the inland territories. The species is characterized by its coarsely rimose, pale fawn-ochre thallus, $\mathrm{C}+$ yellow-orange, $\mathrm{K}-, \mathrm{P}-$, and lecideine apothecia with a persistent proper margin, which is often paler than the disc. Exciple gray-green to gray-blue at the outer part and red-brown inside. The inner part of the exciple contains crystals (pol+), hypothecium deep red-brown, epihymenium blue-green. From a similar species, Lecidella carpathica Körb., it is easily distinguished by its thallus reacting yelloworange with $\mathrm{C}$.

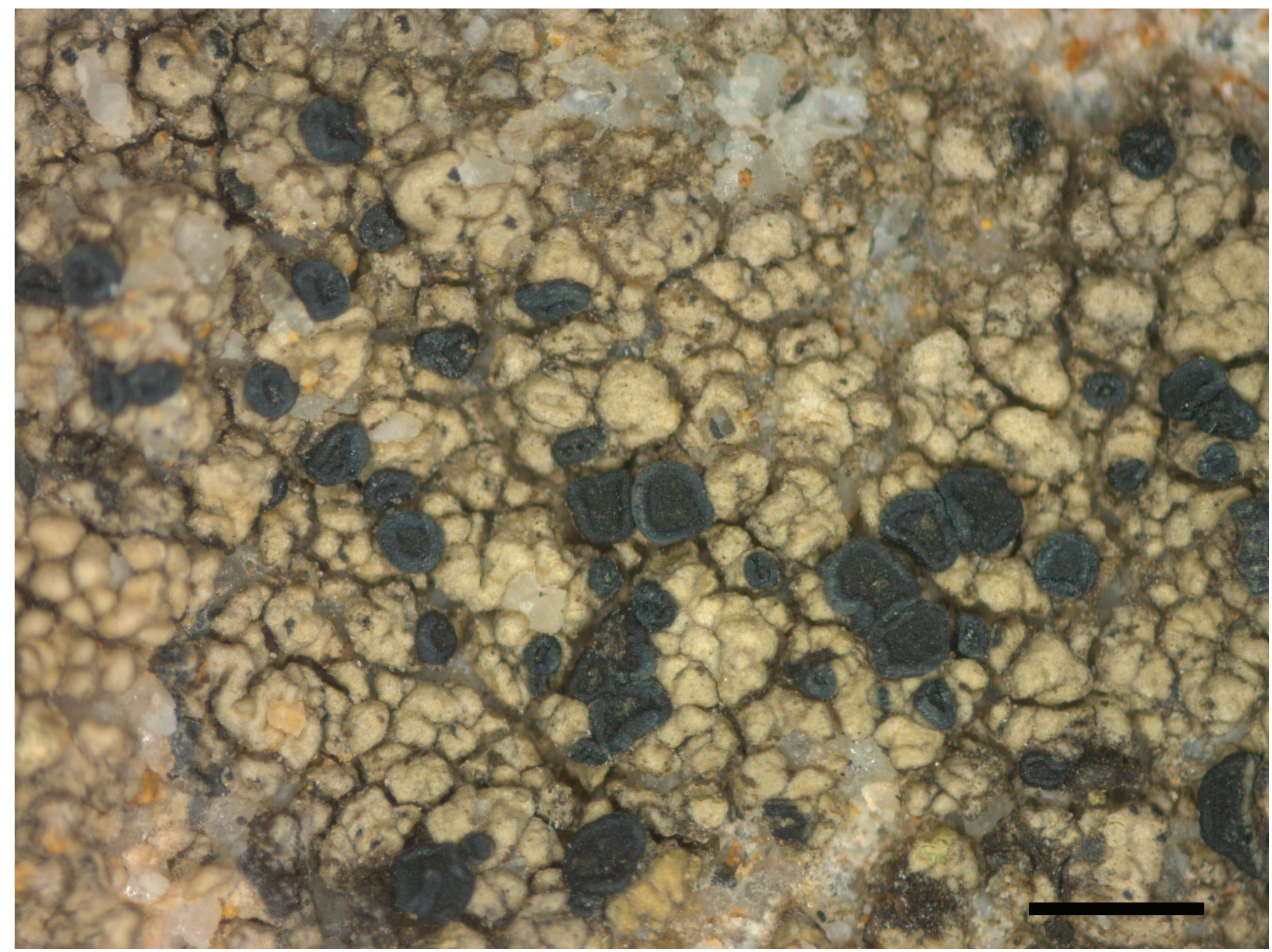

Fig. 6. Lecidella asema (Davydov 18349, Yakovchenko, ALTB). Scale = 1 mm (Photo: E. A. Davydov).

\section{Rinodina gennarii Bagl. (Fig. 7)}

Specimens examined: "Russia, Primorye Territory, Khasanskiy District: Khudova Bay, $46^{\circ} 58^{\prime} 38.85^{\prime \prime} \mathrm{N}, 142^{\circ} 46^{\prime} 37.41^{\prime \prime} \mathrm{E}$, elev. $2 \mathrm{~m}$, seaside cliffs, on rock. 8 V 2013, I. A. Galanina Kh-13-1" (VLA).

Rinodina gennarii is characterized by its small ( $<17.5 \mu \mathrm{m}$ long), Dirinaria-type spores, saxicolous habitats, and a coastal distribution. It has a worldwide distribution in temperate regions of the Northern and Southern Hemispheres growing on maritime rocks (Trinkaus et al., 1999; Sheard et al., 2017). It is hard to mention the true distribution of the species in Russia because Kotlov (2008) regarded specimens growing on bark and on rock as the same species apparently describing the distribution of a mixture of two taxa, $R$. gennarii and $R$. oleae Bagl. Then, in the Checklist of lichens of Russia $R$. gennarii was 
referred as a synonym of $R$. oleae (Urbanavichus, 2010 ), although $R$. gennarii is a primarily saxicolous species on maritime rocks occasionally growing on wood pilings at the seashores, whereas $R$. oleae is a corticolous species and is widely distributed in Eurasia and North America (Sheard, 2010; Sheard et al., 2017). In the East Asian region the confirmed records of $R$. gennari have been made in Japan (Sheard et al., 2017), Kunashir Island (Bredkina et al., 1992; Tchabanenko, 2002), and Sakhalin Island (Konoreva et al., 2018). Here we report it for the first time to the mainland part of the Russian Far East from Primorye Territory.

Similar species having Dirinaria-type spores, $R$. albertana Sheard, R. metaboliza Vain., are also found on bark. Both species differ from $R$. gennarii by the larger spore (> $18 \mu \mathrm{m}$ long).

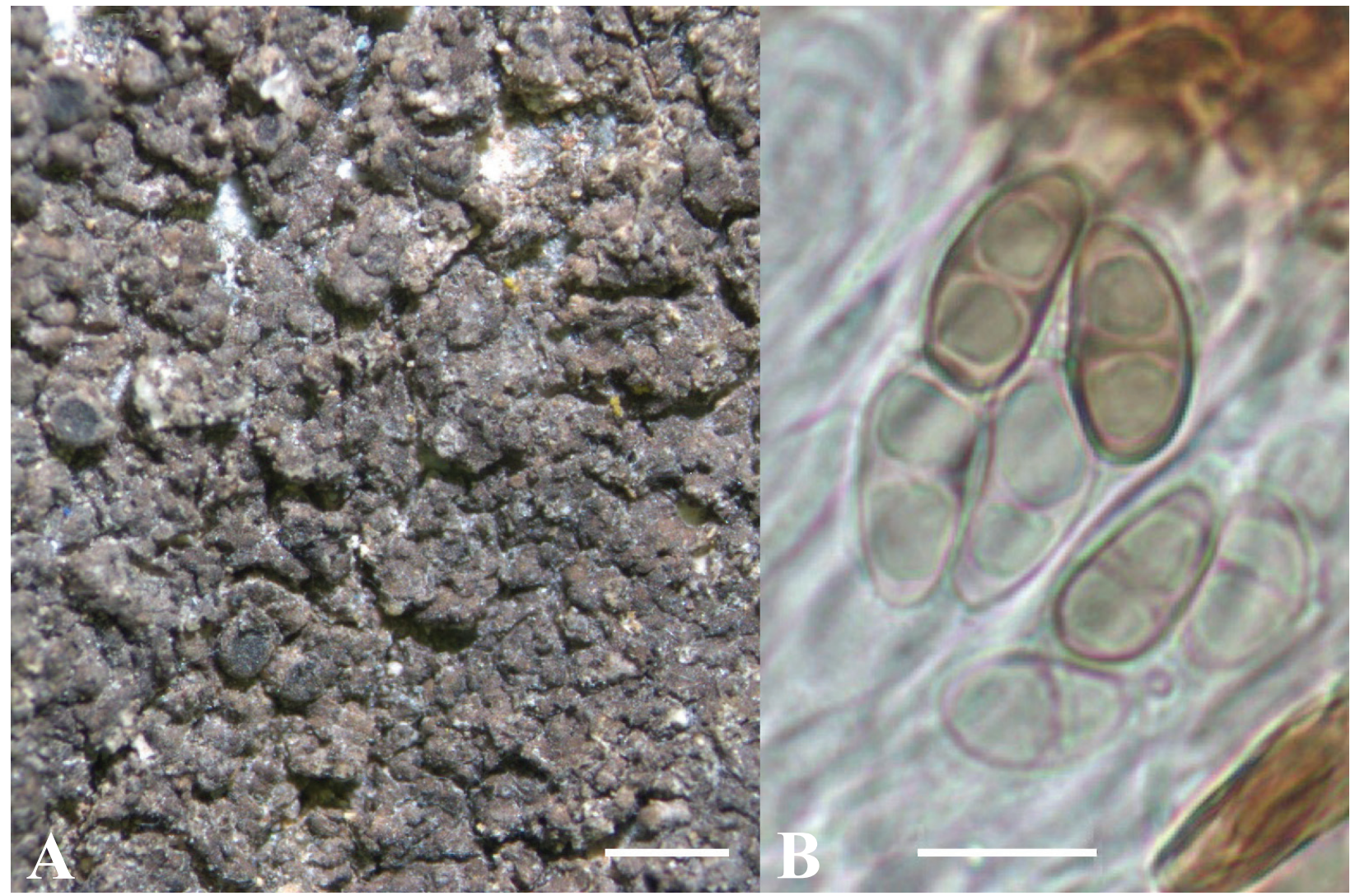

Fig. 7. Rinodina gennarii (Galanina Kh-13-1, VLA). A. Thallus and apothecia. Scale $=0.5 \mathrm{~mm}$. B. Ascospores of Dirinaria type. Scale $=10 \mu \mathrm{m}$ (Photo: I. A. Galanina).

\section{The records of noteworthy species}

Caloplaca atroflava (Turner) Mong. s. 1. (Fig. 8) Specimen examined: "Russia, Sakhalin Island, Sakhalin Region, Makarov District, around cape Tikhiy, $19 \mathrm{~km} \mathrm{~N}$ of Vzmor'e, 48 $01^{\prime} 29.0^{\prime \prime} \mathrm{N}$, $142^{\circ} 32^{\prime} 58.2^{\prime \prime}$, elev. $5 \mathrm{~m}$, siliceous outcrops on the seashore, on rocks. 26 VI 2019. I. V. Frolov" (hb. I. V. Frolov).

This is a common lichen in the Sakhalin Island. It grows on siliceous outcrops along the seashore and on siliceous boulders in rivers. It is known from Europe, Asia, and North America (Fletcher, Laundon, 2009). In Russia, the species is known from the north of the European part and in South
Siberia and Primorye Territory (Urbanavichus, 2010; Skirina, 2016; Vondrák et al., 2019). The species is a one of the most widespread taxa of the so-called C. xerica group (sensu Vondrák et al., 2012). Caloplaca atroflava s. 1. has a thin, areolate, grey thallus and zeorine apothecia with the thalline exciple of the same colour as the thallus and an orange-red disk. The proper exciple and disk in Caloplaca atroflava s. 1. have a negative reaction with $\mathrm{C}$ (contains non-chlorinated anthraquinones). Besides a normal form, lacking vegetative propagules, Caloplaca atroflava s. 1. has a form with poorly or well-developed blastidia (Vondrák, unpublished). In the Sakhalin Island we found both morphotypes, with and without blastidia. 


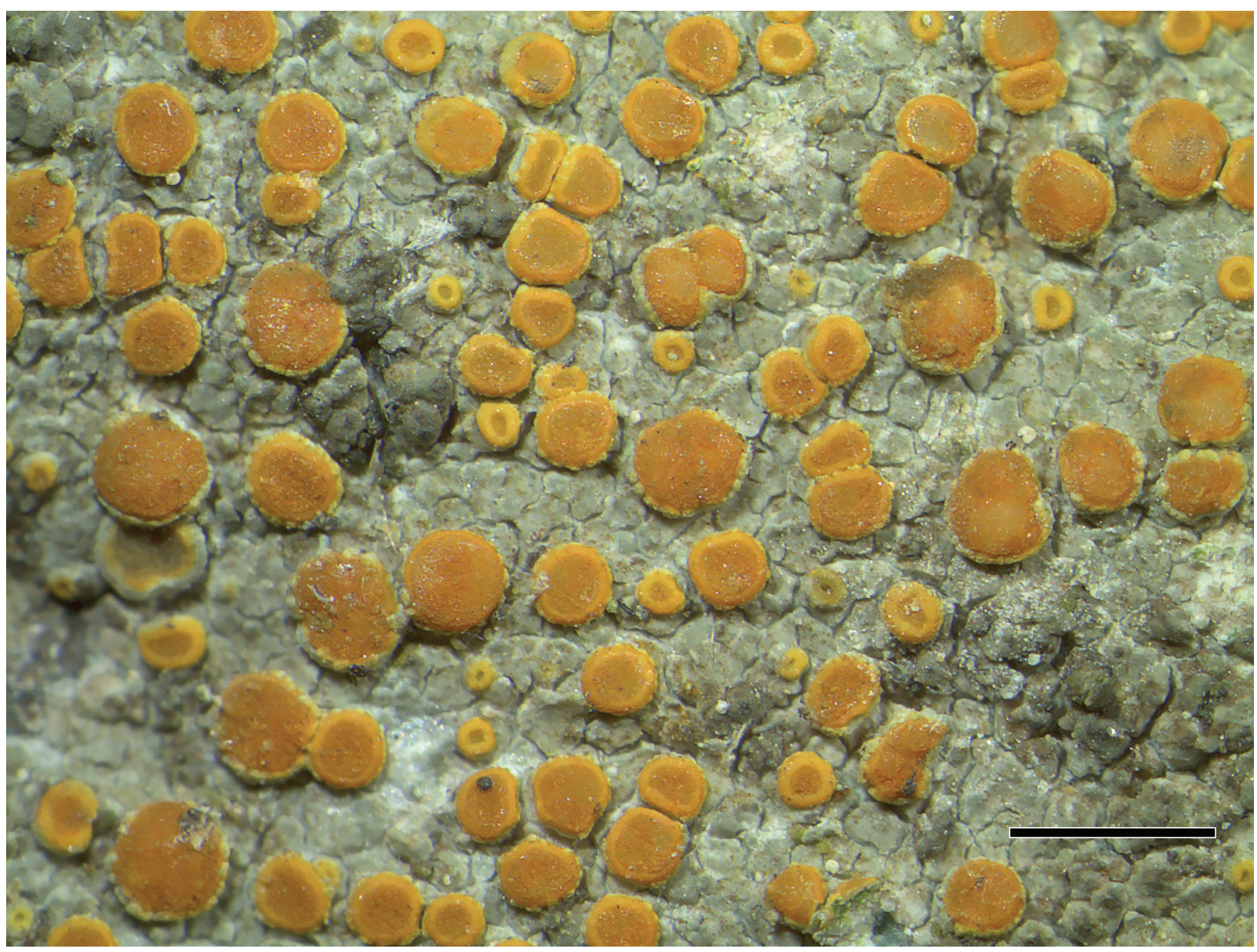

Fig. 8. Caloplaca atroflava from Sakhalin Island (Frolov s. n., hb. Frolov). Scale =1 mm (Photo: I. V. Frolov).

\section{Cladonia subconistea Asahina}

Chemistry: atranorin and traces of fumarprotocetraric acid (TLC ED 20-05).

This lichen containing atranorin and fumarprotocetraric acid was earlier described as Cladonia kurokawae Ahti et Stenroos (Ahti et al., 1996). However, in a multilocus molecular phylogenetic study Pino-Bodas et al. (2013) synonymized this species with $C$. subconistea containing atranorin and psoromic acid. Further these taxa appear to be morphologically very close. Both chemotypes are widespread in China (also in Taiwan), Japan and Korea (ibid.). Cladonia subconistea is an East Asian endemic reported from the Russian Far East by Tchabanenko (2002) on the basis of the material (with psoromic acid) from the herbaria $\mathrm{H}$ and TU identified by T. Ahti. Cladonia subconistea is not the only species in the genus Cladonia, which has taxonomically insignificant strains with psoromic acid. These strains are also known in C. stellaris (Opiz) Pouzar et Vězda, C. symphycarpa (Ach.) Fr., C. furcata (Huds.) Schrad., and C. pocillum (Ach.) Grognot (Ahti,
Stenroos, 2013). Cladonia kurokawae and Cladonia subconistea may still be separate species and require further examination.

Specimens examined: "Russia, Primorye Territory, $\mathrm{N}$ coast of Russkiy Is., to $\mathrm{E}$ of Vyatlin Cape, rocks, $42^{\circ} 57^{\prime} 38^{\prime \prime} \mathrm{N}, 131^{\circ} 54^{\prime} 26^{\prime \prime} \mathrm{E}$, elev. $10 \mathrm{~m}$, on sandstone. 14 VIII 2014. E. A. Davydov 19312, L. S. Yakovchenko" (ALTB).

\section{Leptotrema lithophila Oxner}

Chemistry: no substances (TLC ED1501-17, TLC ED1501-19).

This rare species was described by Oxner (1960) as an endemic to Sikhote-Alin Range based on a single specimen collected in Primorye Territory. Later it was found in Kamchatka Peninsula (Mikulin, 1990). The species was listed in the checklists of lichens of the southern Far East (Tchabanenko, 2002) and Russia (Urbanavichus, 2010) as well as reported in a locality ca. $50 \mathrm{~km}$ to the south-west from the locus classicus (Cherdantseva et al., 2013). All reported collections of the species were made in upland localities at least $25 \mathrm{~km}$ from the seashore. 
Here we are reporting Leptotrema lithophila from the coastal habitats for the first time. Leptotrema litophila is characterized by having a crustose, grey, continuous and irregular thallus that would soon partly flake away from the rocky substrate, with numerous inclusions of calcium oxalate crystals and sunken, pruinose myriotremoid-type to lepadinoidtype apothecia. The lower surface has numerous root-like heavy-branched outgrowths. Morphologically this species resembles some representatives of Diploschistes that is not a close relative to Leptotrema.

Specimens examined: "Russia, Primorye Territory, Dal'negorskiy District: at $1.5 \mathrm{~km} \mathrm{SW}$ from the Lidovka Settlement, $44^{\circ} 24^{\prime} 22^{\prime \prime} \mathrm{N}, 135^{\circ} 52^{\prime} 25^{\prime \prime} \mathrm{E}$, elev. $25 \mathrm{~m}$, Japan Sea coast, foothills of SikhoteAlin Range, gravel barrens covered by shrubs, on siliceous rocks. 17 VIII 2014. L. S. Yakovchenko, E. A. Davydov 12304" (ALTB).

\section{Umbilicaria vellea (L.) Hoffm.}

This is a locally rare but a widespread species in the Russian Far East. In Kamchatka it grows on shaded and humid vertical slopes of old volcanic rocks as well as on the seashore cliffs (Davydov et al., 2011). Umbilicaria vellea has been reported to the Kuril Islands as a whole in "The Lichen Flora of Russia" (Davydov, 2017) on the basis of the following single collection, here documented for the first time in detail.

Specimens examined: "Russia, Sakhalin Region, Paramushir Is., Shelikhova Cape, $\left[50^{\circ} 22^{\prime} 38^{\prime \prime}\right]$ N,

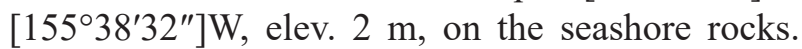
8 VIII 1997. S. I. Tchabanenko 38L/739" (ALTB L-6782).

\section{Acknowledgements}

The study of L. S. Yakovchenko and I. A. Galanina was carried out within the framework of the institutional research project no. AAAAA17-117062710098-4 of the Federal Scientific Center of the East Asia Terrestrial Biodiversity FEB RAS. IF worked in the frame of the national project of the Institute Botanic Garden (Russian Academy of Sciences, Ural Branch). IF was partly supported by the Russian Foundation for Basic Research (project no 19-04-00074).

\section{REFERENCES / ЛИTEPATУРA}

Ahti T., Stenroos S. 2013. Cladoniaceae. In: Nordic Lichen Flora. Eds. T. Ahti, S. Stenroos, R. Moberg. Vol. 5. Uppsala: Museum of Evolution. 117 pp.

Ahti T., Stenroos S., Chen J. B., Guo S. Y. 1996. The status of Cladonia humilis in East Asia. Mycosystema 8/9: 53-58.

Arup $\boldsymbol{U}$. 2006. A new taxonomy of the Caloplaca citrina group in the Nordic countries, except Iceland. The Lichenologist 38(1): 1-20. DOI: 10.1017/S0024282905005402

Blaha J., Grube M. 2007. The new species Lecanora bicinctoidea, its position and considerations about phenotypic evolution in the Lecanora rupicola group. Mycologia 99(1): 50-58. DOI: 10.1080/15572536.2007.11832600

Bredkina L. I., Dobrysh A. A., Makarova I. I., Titov A. N. 1992. To the lichen flora of the Kunashir Island (The Kuril Islands). Novosti sistematiki nizshikh rasteniy [Novit. Syst. Pl. non Vasc.] 28: 90-94. [In Russian] (Бредкина Л. И., Добрыш А. А., Макарова И. И., Титов А. Н. К флоре лишайников острова Кунашир (Курильские острова) // Новости сист. низш. раст., 1992. Т. 28. С. 90-94).

Cherdantseva V. Ya., Bakalin V. A., Yakovchenko L. S., Choi S. S. 2013. Bryophyte flora and lichen biota of Litovka Mt. (Livadiysky Range, Russian Manchuria). V. L. Komarov Memorial Lectures 61: 9-49. [In Russian] (Yepданцева В. Я., Бакалин В. А., Яковченко Л. С., Чой С. С. Бриофлора и лихенобиота горы Литовка (Ливадийский хребет, российская Манчжурия) // Комаровские чтения. Вып. 61. Владивосток: Дальнаука, 2013. С. 9-49).

Coppins B. J., Scheidegger C., Aptroot A. 2009. Buellia. In: The Lichens of Great Britain and Ireland. Eds. C. W. Smith, A. Aptroot, B. J. Coppins, A. Fletcher, O. L. Gilber, P. W. James, P. A. Wolseley. London: British Lichen Society, MPG Books Group. Pp. 228-238.

Davydov E. A. 2017. Family Umbilicariaceae Chevall. In: The Lichen Flora of Russia. Genus Protoparmelia, families Coenogoniaceae, Gyalectaceae and Umbilicariaceae. Eds. M. P. Andreyev, D. E. Himelbrant. Moscow-St. Petersburg: KMK Scientific Press. Pp. 66-136. [In Russian] (Давыљљв Е. А. Семейство Umbilicariaceae // Флора лишайников России: род Protoparmelia, семейства Coenogoniaceae, Gyalectaceae и Umbilicariaceae / Отв. ред. М. П. Андреев, Д. Е. Гимельбрант. М.; СПб.: Товарищество научных изданий КМК, 2017. С. 66-136).

Davydov E. A., Himelbrant D. E., Stepanchikova I. S. 2011. Contribution to the study of Umbilicariaceae (lichenized Ascomycota) in Russia. II. Kamchatka Peninsula. Herzogia 24: 229-241. DOI: 10.13158/heia.24.2.2011.251

Davydov E. A., Yakovchenko L. S., Konoreva L. A., Chesnokov S. V., Ezhkin A., Galanina I. 2021. New records of lichens from the Russian Far East. II. Species from forest habitats. Opuscula Phylolichenum 20, in press. 
Edwards B., Aptroot A., Hawksworth D. L., James P. W. 2009. Lecanora. In: The Lichens of Great Britain and Ireland. Eds. C. W. Smith, A. Aptroot, B. J. Coppins, A. Fletcher, O. L. Gilber, P. W. James, P. A. Wolseley. London: British Lichen Society, MPG Books Group. Pp. 465-502.

Esslinger T. L. 2018. A cumulative checklist for the lichen-forming, lichenicolous and allied fungi of the continental United States and Canada, Version 22. Opuscula Philolichenum 17: 6-268.

Fletcher A., Laundon J. R. 2009. Caloplaca. In: The Lichens of Great Britain and Ireland. Eds. C. W. Smith, A. Aptroot, B. J. Coppins, A. Fletcher, O. L. Gilber, P. W. James, P. A. Wolseley. London: British Lichen Society. Pp. 245-273.

Fletcher A., Purvis O. W, James P. W. 2009. Lecidella. In: The Lichens of Great Britain and Ireland. Eds. C. W. Smith, A. Aptroot, B. J. Coppins, A. Fletcher, O. L. Gilber, P. W. James, P. A. Wolseley. London: British Lichen Society, MPG Books Group. Pp. 519-525.

Higashi A., Yoshikawa H., Watanuki O., Harada H. 2017. Marine and maritime lichens of Japan (1). Buellia yoshimurae sp. nov. Lichenology 16: 1-13.

Himelbrant D. E., Stepanchikova I. S., Motiejūnaitè J., Kuznetsova E. S., Tagirdzhanova G., Frolov I. V. 2019. New records of lichens and allied fungi from the Leningrad Region, Russia. X. Folia Cryptogamica Estonica 56: 23-29. DOI: 10.12697/fce.2019.56.04

Kondratyuk S. Y., Lökös L., Park J.-S., Jang S.-H., Jeong M.-H. 2016. New Aspicilia species from South Korea proved by molecular phylogeny with a key to the Eastern Asian aspicilioid lichens. Studia Botanica Hungarica 47(2): 227-249. DOI: 10.17110/StudBot.2016.47.2.227

Konoreva L. A., Tchabanenko S. I., Ezhkin A. K., Schumm F., Chesnokov S. V. 2018. New and noteworthy lichen and allied fungi records from Sakhalin Island, Far East of Russia. Herzogia 31(1): 276-292. DOI: 10.13158/099.031.0123

Kotlov Yu. V. 2008. Rinodina. In: Opredelitel lishaynikov Rossii [Handbook of the lichens of Russia]. Ed. N. S. Golubkova. Vol. 10. St. Petersburg: Nauka. Pp. 309-359. [In Russian] (Котлов Ю. В. Rinodina // Определитель лишайников России. Т. 10. СПб.: Наука, 2008. С. 309-359).

Mikulin A. G. 1990. Handbook of the lichens of the Kamchatka Peninsula. Vladivostok: FESC AS USSR. 128 pp. [In Russian] (Микулин А. Г. Определитель лишайников полуострова Камчатка. Владивосток: ДВО АН СССР, 1990. 128 c.).

Moon K. H. 2013. Lichen-forming and lichenicolous fungi of Korea. Incheon: National Institute of Biological Resources. 139 pp.

Nimis P. L., Martellos S. 2017. ITALIC - The Information System on Italian Lichens. Ver. 5.0. University of Trieste, Department of Biology. URL: http://dryades.units.it/italic (Accessed 23 March 2019).

Ohmura Y., Kashiwadani H. 2018. Checklist of lichens and allied fungi of Japan. National Museum of Nature and Science Monographs 49: 1-140.

Orange A., James P. W., White F. J. 2001. Microchemical methods for the identification of lichens. London: British Lichen Society. $101 \mathrm{pp}$.

Oxner A. M. 1960. New lichen species Leptotrema lithophila sp. n. in flora USSR. Ukrainian Botanical Journal 17(4): 67-74. [In Ukrainian] (Окснер А. М. Новий лишайник Leptotrema lithophila sp. п. у флоры СРСР // Украин. ботан. журнал, 1960. Т. 17, № 4. С. 67-74).

Paukov A., Nordin A., Roux C., Moon K. H., Davydov E. 2017. Lectotypification and synonymization of some Aspicilia species (Megasporaceae, Ascomycota) described by A. Hue from Korea and Japan. Phytotaxa 291 (1): 94-98. DOI: 10.11646/phytotaxa.291.1.10

Pino-Bodas R., Ahti T., Stenroos S., Martín M. P., Burgaz A. R. 2013. Multilocus approach to species recognition in the Cladonia humilis complex (Cladoniaceae, Ascomycota). American Journal of Botany 100: 664-678. DOI: 10.3732/ajb.1200162

Sheard J. W. 2010. The lichen genus Rinodina (Lecanoromycetidae, Physciaceae) in North America, North of Mexico. Ottawa: National Research Council of Canada, NRC Research Press. 246 pp.

Sheard J. W., Ezhkin A. K., Galanina I. A., Himelbrant D., Kuznetsova E., Shimizu A., Stepanchikova I., Thor G., Tonsberg T., Yakovchenko L. S., Spribille T. 2017. The lichen genus Rinodina (Physciaceae, Caliciales) in northeastern Asia. The Lichenologist 49(6): 617-672. DOI: 10.1017/S0024282917000536

Skirina I. F. 2016. Lichens. In: Plants, fungi and lichens of the Sikhote-Alin Reserve. Ed. E. A. Pimenova. Vladivostok: Dalnauka. Pp. 458-525. [In Russian] (Скирина И. Ф. Лишайники // Растения, грибы и лишайники СихотэАлинского заповедника. Ред. Е. А. Пименова. Владивосток: Дальнаука, 2016. С. 458-525).

Skirina I. F., Rodnikova I. M. 2014. Lichens of the islands and terrestrial coastal zone of Far Eastern Marine Reserve. Biota i sreda zapovednikov Dalnego Vostoka [Biota and Environment of Far East Reserves] 2: 92-122. [In Russian] (Скирина И. Ф., Родникова И. М. Список лишайников островов и прибрежных участков Дальневосточного морского биосферного заповедника // Биота и среда заповедников Дальнего Востока, 2014. № 2. С. 92-122). 
Tchabanenko S. I. 2002. Konspekt flory lishaynikov yuga rossiyskogo Dalnego [Synopsis of lichen flora of the South of the Russian Far East]. Vladivostok: Dalnauka. 232 pp. [In Russian] (Чабаненко С. И. Конспект флоры лишайников юга российского Дальнего Востока. Владивосток: Дальнаука, 2002. 232 с.).

Trinkaus U., Mayrhofer H., Matzer M. 1999. Rinodina gennarii (Physciaceae), a widespread species in the temperate regions of the Southern Hemisphere. Australasian Lichenology 45: 15-21.

Urbanavichus G. P. 2010. Spisok likhenoflory Rossii [A checklist of the lichen flora of Russia]. St.-Petersburg: Nauka. 194 pp. [In Russian] (Урбанавичюс Г. П. Список лихенофлоры России. СПб.: Наука, 2010. 194 с.).

Urusov V. M. 2018. Far East and Northern Pacific zenogenesis (Let's draw a line). Vladivostok: PGI FEB RAS. 243 pp. [In Russian] (Урусов В. М. Дальний Восток и Северная Пацифика - ценогенез (подведём черту). Владивосток: ТИГ ДВО РАН, 2018. 243 с.).

Vondrák J., Frolov I., Davydov E. A., Urbanavichene I., Chesnokov S., Zhdanov I., Muchnik E., Konoreva L., Himelbrant D., Tchabanenko S. 2016. The extensive geographical range of several species of Teloschistaceae: evidence from Russia. The Lichenologist 48(3): 171-189. DOI: 10.1017/S0024282916000116

Vondrák J., Frolov I., Davydov E. A., Yakovchenko L., Malíček J., Svoboda S., Kubásek J. 2019. The lichen family Teloschistaceae in the Altai-Sayan region (Central Asia). Phytotaxa 396(1): 1-66. DOI: 10.11646/phytotaxa.396.1.1

Vondrák J., Šoun J., Vondráková O., Fryday A. M., Khodosovtsev A., Davydov E. 2012. Absence of anthraquinone pigments is paraphyletic and a phylogenetically unreliable character in the Teloschistaceae. The Lichenologist 44(3): 401-418. DOI: 10.1017/S0024282911000843

Wang Q.-D., Liu F.-Y., Wu X.-H., Zhao X., Jia Z.-F. 2018. Buellia taishanensis sp. nov. and new Buellia records from Mt. Tai, China. Mycotaxon 133(1): 165-172. DOI: 10.5248/133.165

Yakovchenko L. S., Davydov E. A., Paukov A. G., Ohmura Y. 2019. New records of lichens from the Russian Far East. I. Fuscidea submollis and other arctic-alpine species. Turczaninowia 22, 3: 91-96. DOI: 10.14258/turczaninowia.22.3.4

Yakovchenko L., Davydov E. A., Paukov A., Konoreva L., Chesnokov S., Ohmura Y. 2020. New records of arcticalpine lichens from the Russian Far East. Herzogia 33(2): 455-472. 